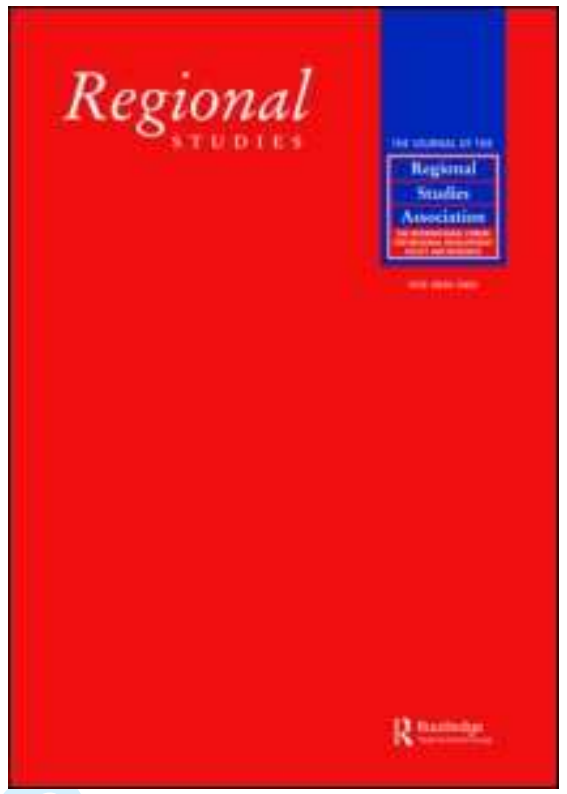

\title{
INDUSTRIAL ECOLOGY AND REGIONAL DEVELOPMENT: ECO- INDUSTRIAL DEVELOPMENT AS CLUSTER POLICY
}

\begin{tabular}{|r|l|}
\hline Journal: & Regional Studies \\
\hline Manuscript ID: & CRES-2005-0170.R2 \\
\hline Manuscript Type: & Main Section \\
\hline JEL codes: & $\begin{array}{l}\text { O18 - Regional, Urban, and Rural Analyses < O1 - Economic } \\
\text { Development < O - Economic Development, Technological Change, } \\
\text { and Growth, O21 - Planning Models|Planning Policy < O2 - } \\
\text { Development Planning and Policy < O - Economic Development, } \\
\text { Technological Change, and Growth, Q01 - Sustainable Development } \\
\text { R11 - Regional Economic Activity: Growth, Development, and } \\
\text { Changes < R1 - General Regional Economics < R - Urban, Rural, } \\
\text { and Regional Economics }\end{array}$ \\
\hline \hline Keywords: & $\begin{array}{l}\text { Industrial ecology , clusters, eco-industrial parks , networking, } \\
\text { regional development, trust }\end{array}$ \\
\hline \hline
\end{tabular}

\section{SCHOLARONE" Manuscripts}


Pauline Deutz* and David Gibbs**

Department of Geography

University of Hull

Hull

HU6 7RX

*corresponding author:p.deutz@hull.ac.uk

**d.c.gibbs@hull.ac.uk

Paper submitted to Regional Studies August 2005

Accepted February 2008 


\title{
INDUSTRIAL ECOLOGY AND REGIONAL DEVELOPMENT: ECO-
}

\section{INDUSTRIAL DEVELOPMENT AS CLUSTER POLICY}

\begin{abstract}
Aspects of industrial ecology fit closely with work in regional development investigating clustering, networking, and local economic development. However, there has been limited cross fertilisation between these bodies of literature. This paper uses an empirical focus on eco-industrial developments in the USA to postulate that industrial ecology can be viewed as a distinct cluster concept and to consider the implications of this for both industrial ecology and regional development policies.
\end{abstract}

Key words

Industrial ecology eco-industrial parks industrial symbiosis regional development clusters networking JEL L14 R38 R58

L'écologie industrielle et l'aménagement du territoire: le développement industriel écologique comme politique d'agglomération.

Deutz \& Gibb

Des aspects de l'écologie industrielle sont en corrélation étroite avec des recherches dans le domaine de l'aménagement du territoire qui examinent l'agglomération, la connexion et le développement local économique. Cependant, il y a eu peu de synergie entre ces faisceaux de documentation. Cet article porte de façon empirique sur les développements industriels écologiques aux E-U afin de postuler que l'on peut envisager l'écologie industrielle comme une notion indéniable d'agglomération et en considérer les retombées à la fois pour l'écologie industrielle et les politiques d'aménagement du territoire.

Ecologie industrielle / Parcs industriels écologiques / Symbiose industrielle / Agglomérations régionales / Connexion

Classement JEL: L14; R38; R58 


\title{
Industrieökologie und Regionalentwicklung: öko-industrielle Entwicklung als Cluster-Politik \\ Pauline Deutz and David Gibb
}

\begin{abstract}
Die Aspekte der Industrieökologie sind eng mit der Arbeit der

Regionalentwicklung verzahnt, was die Untersuchung von Clusterbildungen, Netzwerken und lokaler Wirtschaftsentwicklung anbelangt. Die gegenseitige Befruchtung zwischen diesen Literaturkörpern fiel jedoch bisher eher begrenzt aus. In diesem Beitrag wird anhand eines empirischen Fokus auf den ökoindustriellen Entwicklungen in den USA postuliert, dass sich die Industrieökologie als eigenständiges Cluster-Konzept betrachten lässt, und es werden die Auswirkungen auf die Politiken für Industrieökologie und Regionalentwicklung untersucht.

Key words

Industrieökologie

Öko-Industrieparks

Industriesymbiose

Regionalentwicklung

Cluster

Netzwerke
\end{abstract}

JEL L14 R38 R58

Ecología industrial y desarrollo regional: desarrollo ecoindustrial como política de aglomeración

Pauline Deutz and David Gibb

\author{
ABSTRACT \\ Los aspectos de la ecología industrial están estrechamente vinculados al \\ trabajo en el desarrollo regional que estudia la aglomeración, las redes y el \\ desarrollo económico local. Sin embargo, la mutua hibridación entre estos \\ organismos de literatura ha estado limitada. En este artículo usamos un \\ enfoque empírico sobre los desarrollos ecoindustriales en los EE.UU. para \\ postular que la ecología industrial puede considerarse un concepto distintivo \\ de aglomeraciones y para considerar qué efectos tiene esto en la ecología \\ industrial y las políticas de desarrollo industrial. \\ Key words \\ Ecología industrial \\ Parques ecoindustriales \\ Simbiosis industrial \\ Desarrollo regional \\ Aglomeraciones \\ Redes \\ JEL L14 R38 R58
}




\section{INTRODUCTION}

Over some fifteen years the industrial ecology (IE) and regional development (RD) literatures have shared an interest in the theories and practices of industrial agglomeration, interfirm networking and their potential contribution to regional development. Academic interest in agglomeration relates to the apparently paradoxical persistence of regional economic disparities in the age of the 'knowledge economy' and electronic communications (CUMBERS and MACKINNON, 2004). Policy interest in industrial agglomeration, largely derived from PORTER'S work on clusters (e.g., 1998) (MARTIN and SUNLEY, 2003) lies in its perceived potential as an engine for regional development through the attempted transfer of features from successful to lagging regions. Some writers have debated whether regional success can be duplicated, and indeed whether the region is an appropriate scale of analysis, given for example, the interdependence of regions, the importance of national policies and historic contingencies (LOVERING, 1999; RACO, 1999; MORGAN, 2004). Nevertheless, cluster-based policies remain firmly entrenched in many national and regional economic development strategies (CUMBERS and MACKINNON, 2004). Industrial clusters have been defined as 'loose networks of independent economic agents in the same or related market segment and restrictive geographic locality' (HENDRY and BROWN, 2006; p. 708). Cluster approaches to regional development observe that clustering confers an economic advantage on participants over non-participants and that these advantages can have beneficial spill-over effects on the host community. The regional development literature on clusters incorporates a range of theoretical perspectives offering different explanations for regional economic disparities. The ambiguities of the term 'cluster' and consequent limitations on its usefulness as either a source of theory or as a policy tool have been 
widely discussed (e.g., MACKINNON et al., 2002; BATHELT, 2005). Following BENNEWORTH and HENRY (2004) we use the term 'clusters' as an umbrella concept for agglomerations of interlinked businesses and institutions, rather than a precisely, but variously, defined term.

An emerging theme in regional development in theory and practice is the need to address environmental issues (HAUGHTON and COUNSELL, 2004; GIBBS, 2006), which have received relatively little attention in the regional development literature (RACO, 1999). In the UK, the regional level of government has been given an enhanced planning role, with the advent of the requirement for Regional Spatial Strategies (RSS) (HAUGHTON and COUNSELL, 2004). The RSS covers a large range of issues, with the environment, including waste and energy, being amongst them. A comparable national drive to promote an integrated approach to regional planning does not exist in the US. However, ideas such as New Regionalism and Smart Growth do promote consideration of the environment in US regional and urban development (e.g., JONAS and PINCETL, 2006; SCOTT, 2007). These movements as 'bottom up' approaches are distinct from the 'top down' policy driven New Regionalism that LOVERING (1999) and others refer to in the UK context (JONAS and PINCETL, 2006).

One way to address these environmental concerns is through the adoption of ideas from industrial ecology which propose that industry can learn from the example of natural ecosystems and can be reorganised to form 'industrial ecosystems'. More specifically, industrial ecologists envisage such industrial ecosystems as involving a dense network of material interchanges between proximate firms. While some industrial ecologists have viewed eco-industrial developments as a form of cluster (GERTLER, 1995; COHEN-ROSENTHAL and MCGALLIARD, 1998; BAAS and 
BOONS, 2004), research work in industrial ecology has paid little attention to either theoretical or policy debates in the regional development literature. Similarly, those working in the regional development field have largely ignored developments in industrial ecology (GIBBS, 2003).

Bringing the regional development and industrial ecology literatures together can have benefits for researchers in both fields. Drawing upon the lessons of cluster development may help to explain the difficulties of policy implementation for industrial ecology projects, as well as providing a more rigorous theoretical context to a predominantly normative literature. Conversely, for those involved with regional development policy, industrial ecology provides guidelines as to how the environmental impact of economic development can be ameliorated, a key consideration in an age of concern over climate change. However, in order to consider the potential for a fruitful cross fertilisation of ideas from IE and RD, it is first imperative to situate them in a common framework. Thus the primary research question for this study is to investigate on the basis of theoretical arguments and empirical evidence whether IE is simply an environmentally explicitly version of an existing approach to RD, or should it be seen as a distinct perspective? Given the multiplicity of approaches to clusters within RD (e.g., BENNEWORTH and HENRY (2004), the basis for our comparison of IE and RD cluster perspectives will be the theoretical and empirical treatment of the three meta-themes of external economies of scale, networking and policy. As we will show below, these themes are important in varying ways to all the recognised cluster perspectives and are also prominent in the IE literature. We will argue that IE should be seen as a distinct cluster perspective, which generates the second research question: what are the policy implications for IE and $\mathrm{RD}$ of recontextualising IE as a cluster perspective? 
The structure of the paper is as follows. In the next section we outline the main features of industrial ecology and its implementation in the form of ecoindustrial parks. We then turn to a review of the clusters literature to examine its approaches to the three meta-themes, in order to provide the context for the subsequent examination of how eco-industrial developments can be (re)conceived as a clustering strategy. The paper then draws upon empirical work on nine US ecoindustrial parks (EIPs), representing a range of developmental stages, to present EIPs as a cluster-based, yet distinctive perspective, on regional development. In the conclusions, we present policy implications for both regional development and industrial ecology arising from this contextualisation.

\section{INDUSTRIAL ECOLOGY AND ECO-INDUSTRIAL DEVELOPMENT}

Industrial ecology is a business-oriented initiative aiming to decrease the impact of business on the environment by promoting the 'win-win' of eco-efficiency i.e. that environmental savings (e.g., reducing material and energy consumption) can also bring cost savings. IE is characterised by its promotion of 'industrial ecosystems', involving inter-company co-operation, derived from a metaphor with natural ecosystems (e.g., FROSCH and GALLOPOULOS, 1989; AYRES, 1989; WELLS, 2006). A number of principles can be derived from this metaphor. KORHONEN (2001) refers to these as roundput; diversity; locality and gradual change. Roundput is the recycling and cascading of matter and/or energy between either natural or industrial ecosystem members. Diversity relates to biodiversity in natural ecosystems with interdependency and co-operation between different species and/or different organisms of the same species. In industrial terms this concept implies interdependency and co-operation between companies potentially engaged in different 
industrial sectors as well as other actors (e.g., government or non-governmental bodies). Diversity is important, so the range of inputs required may match the range of outputs offered. Locality in both ecosystem and industrial systems relates to awareness of, and respect for, local resources and local limiting factors and also the spatial scale of interdependences (networks of industrial symbioses in economic terms). Gradual change for ecosystems relates to change through evolution and use of resources at a rate at which they are replenished. KORHONEN (2001) contrasts this with the rate of change in industrial systems and calls for a use of renewable resources within their rate of replenishment. In essence, in an industrial ecosystem one company's by-products or surplus heat become another's raw material or energy essentially the concept of 'waste' is replaced by one of 'residuals' (ALLENBY, 1999). Thus, IE takes a systems rather than firm-oriented view to eco-efficiency, with the expectation that this will increase the possibilities for eco-efficiencies at the system, or regional, scale.

Industrial symbiosis (IS) is a place-based approach to IE, which concerns networks of companies exchanging by-products. Much of the industrial ecology perspective on clustering is derived from observations of the symbiosis network developed around the Danish town of Kalundborg. As widely described (e.g., GERTLER, 1995; CHERTOW, 2000; DESROCHERS, 2002; CHERTOW et al., this volume), over approximately 25 years a complex web of interchanges evolved at Kalundborg including the transfer of fly ash from the power station to a cement plant, use of excess heat from the power station for district heating, and transfer of wastewater from the oil refinery to the power station. Despite a backdrop of environmental regulations that encouraged firms to seek alternatives to traditional waste disposal options, the emerging network and its environmental benefits was not noticed until 
some 15 years after the initial exchanges were agreed on the basis of mutual financial interest (CHERTOW, 2000). Other IS networks have since been identified e.g., Styria, Austria and the petrochemical complex at Sarnia, Ontario, Canada (DESROCHERS, 2002).

A growing policy interest in applying the lessons of Kalundborg in other locations has led to the development of eco-industrial initiatives. In some cases these have been organised on a regional scale, in others around co-located firms in an ecoindustrial park, or a mixture of both. An eco-industrial park (EIP) has been defined as a:

...community of businesses that co-operate with each other and with the local community to efficiently share resources (information, materials, water, energy, infrastructure and natural habitat), leading to economic gains, gains in environmental quality and equitable enhancement of human resources for business and local community. (PCSD, 1997: 6).

Industrial ecology initiatives frequently display an imbalance between ideals and practice (CHERTOW, 1999; HEERES et al., 2004; GIBBS and DEUTZ, 2005). With respect to the operational parks, there is a debate on the defining characteristics of an EIP (see GIBBS et al., (2005) and CHERTOW (2007) for a review of the IE literature; and PELLENBARG (2002) for a review of the Dutch policy-oriented debate). Similar components to EIPs are identified in either case, with symbiosis being the ultimate, but elusive, goal. VAN LEEUWEN et al. (2003) define a threefold classification of 'eco-cooperation options' (p. 153). The most ambitious of these is symbiosis, with its concomitant environmental and economic benefits, but also technological, organisational and social barriers (i.e., principally the need to build trust). We have previously stated that some evidence of symbiosis should be present for a park to be considered an EIP, though accomplishing that may be a long term goal (GIBBS et al., 2005). CHERTOW (2007) further states that an IS network (not 
necessarily park based) at a minimum should comprise 3 companies exchanging at least 2 different by-products. VAN LEEUWEN et al.'s intermediate option is utility sharing. This includes joint purchase of energy or waste services. It involves less interfirm co-operation but also offers fewer environmental benefits than IS. The third option they refer to as 'spatial planning' (p. 154), i.e., the collective design of park features, such as the location and landscaping of open spaces. This brings the least environmental benefits of the three options.

A number of authors have identified industrial symbiosis as a potential area for public sector intervention, in that it could provide a means to both implement environmental regulations and promote economic development. However, whereas some (e.g. ANDREWS, 1999) have simply called for more environmentally sensitive economic development and urged caution as to the potential for planned EIPs, others (e.g., LOWE, 1997; SCHLARB, 2001) have seen a major role for the active promotion of eco-industrial development as a tool for local and regional economic development. Although the links are not made explicit, the implementation of IE as a policy initiative is effectively an environmentally-based variant of the types of cluster policy that have been widely applied in economic development initiatives in recent years (see below). Thus, EIP developers are striving for not just an agglomeration of businesses (i.e., a standard industrial park), but an agglomeration with links between the businesses, i.e., a cluster. We now turn to a review of the clusters literature in regional development to provide some more detailed context.

\section{CLUSTER PERSPECTIVES IN REGIONAL DEVELOPMENT}

The purpose of this section is to present our three key meta-themes of external economies of scale, networking and policy, which we will use to review both the IE 
literature and our case studies. There is an extensive regional development literature offering a range of theoretical perspectives on the cluster concept. A comprehensive review is not possible here (see STORPER (1997), NEWLANDS (2003) and BENNEWORTH and HENRY (2004) for overviews) but six main perspectives can be identified:

1. Industrial districts: agglomeration economies (co-located small companies enjoying the economies of scale otherwise confined to larger operations) originating with Alfred Marshall (MARSHALL, 1890); the benefits relate to access to a common pool of labour, shared services, and trade between companies within the agglomeration.

2. New industrial districts (NID): Small companies exploit a market niche by specialising, but gain flexibility by co-operating with co-located companies with compatible interests. Co-operation is founded on social and business related contact between individuals (PIORE and SABEL, 1984); based on observations of the Third Italy and southern Germany. The concept of 'untraded interdependencies' (STORPER, 1997) emphasises the benefits of inter-firm cooperation founded on trust and exchange of tacit knowledge.

3. Transaction cost theory: in the era of post-Fordist vertical and horizontal disintegration companies face a potentially costly increase in the number of external transactions. However, trust built of personal contact with proximal firms reduces the complexity and thus costs of transactions (e.g., SCOTT, 1988).

4. Innovation and high technology: seeks to explain location of high-technology industries, which are considered a driver for regional development (e.g., SAXENIAN, 1995); includes the concept of innovative milieux in which a network of local businesses and institutions (e.g., of learning and policy making) 
provide a supportive environment for innovation (e.g., PERRIN, 1993, in STORPER, 1997).

5. Institutional and evolutionary economics: technological developments are part of the drive for competitiveness characteristic of capitalism; development is 'path dependent' with present-day agglomerations the result of historical events. 'Institutional thickness' emphasises the role of extra-firm organisations (AMIN, 1999: SYDOW and STABER, 2002).

6. Porter's 'strategic management' concept of clusters: draws on agglomeration economies, but emphasises interfirm networking (PORTER, 1998). Businesses within a cluster may share a common value chain, or alternatively comprise competitors in a common industry (BATHELT, 2005).

Whilst each perspective is distinctive, they substantially overlap and the boundaries between them debatable (NEWLANDS, 2003). Therefore, rather than elaborate on each perspective in detail, we distil three key meta-themes: external economies of scale; networking; and policy, where the first two relate to explanations for the benefits of clustering. Our description of these meta-themes cannot provide a full picture of the nuances of each perspective, but we subsequently use these here to provide a basis to reanalyse eco-industrial initiatives from the perspective of the clusters literature.

External economies of scale

This meta-theme is the essence of agglomeration theories and refers to the shared access to factors of production and supporting institutions. In all the perspectives on clustering, a central theme is that companies have access to benefits that they cannot provide internally and for which they would not by themselves constitute a sufficient market to support an external provider. Deriving from the original work of 
MARSHALL (1890) on industrial districts, this meta-theme displays varying degrees of prominence in all the other perspectives. The notion of external (to the firm) economies of scale concerns not just the relationships between manufacturers themselves, but emphasises the potential for firms to benefit from shared access to goods and services, such as a pool of suitably qualified and/or experienced labour, or financial and legal firms. In PORTER'S (1998) conceptualisation of clusters, agglomeration economies are central to the competitive advantage afforded to participating businesses. The new industrial districts approach also draws on Marshall's ideas, but in addition stresses the benefits to business of social cohesion and personal contact (AMIN, 2000). A parallel can also be drawn between MARSHALL'S work emphasising agglomeration benefits, such as a shared labour pool, and other research emphasising the importance of institutions in catalysing potentially innovative collaborations (STORPER, 1997). The involvement of institutions such as universities is part of the explanation for success for regional development based on innovation and high technology approaches (SAXENIAN, 1985).

\section{Networking}

This meta-theme relates to opportunities for face-to-face contact between representatives of different companies and organisations, which helps to generate benefits most succinctly summed up as 'untraded interdependencies', as well as reducing the cost of monetary-based transactions between firms. Given the ability of firms to source goods (and services) globally, locational advantages are assumed in part to reflect the dynamics of personal contact (e.g., AMIN, 1999, MORGAN, 2004). The importance of personal contact and familiarity came originally from the new industrial districts conceptualisation of agglomeration benefits (PIORE and SABEL, 
1984; AMIN, 2000). The institutionalist perspective emphasises that economically successful agglomerations may be differentiated from others by the presence of key institutions mediating interfirm collaborations (STORPER, 1997).

Personal contact, be it institutionally mediated, purely social, or the result of an employee moving between companies helps generate trust between individuals (PIORE and SABEL, 1984; STORPER, 1997). The resulting benefits fall into two categories as exemplified by two of the perspectives on clusters. First, the transaction cost perspective emphasises the benefits of a greater willingness to do business with a firm with which there is a personal link. This is particularly true in complex circumstances, as opposed to a straightforward buyer-seller relationship (STORPER, 1997). Thus if trust is present, time and money are saved by avoiding having to draw up a water-tight contract or build a personal relationship. Second, the concept of 'untraded interdependencies' captures the benefits of contact not related to formal monetary transactions. One such is the exchange of tacit knowledge - knowledge which cannot be readily written down, or 'codified' (HOWELLS, 2002). Knowledge and its exchange are significant precursors to innovation, itself a key determinant of a firm's competitiveness (e.g., MORGAN, 1997). The concept of innovative milieu also draws on the importance of personal contact and tacit knowledge (CAMAGNI, 1991).

Policy

Policy makers have displayed, and continue to display, substantial interest in cluster formation as a regional development initiative worldwide (MARTIN and SUNLEY, 2003; CUMBERS and MACKINNON, 2004; ST. JOHN and POUDER, 2006). One inspiration is the evident economic growth stemming from the innovations emerging from successful clusters such as the IT industry in Silicon Valley. However, the 
academic literature on regional development is far more ambivalent about the role for policy initiatives in cluster formation and the necessity of 'institutional thickness'. Much of this literature advises against attempting to create clusters de novo as opposed to nurturing clusters based on existing local/regional potential (MARTIN and SUNLEY, 2003). Thus, the role for policy in cluster initiatives is confined to providing assistance where the market has failed and where, despite some form of agglomeration, the expected benefits have not emerged (NEWLANDS, 2003). Policies may consist of providing opportunities or encouragement for one of the other meta-themes above, e.g., for external economies (joint marketing, shared business services); targeting to recruit the types of firms/organisations that are missing (e.g., from the supply chain); or providing opportunities for contact between firms, i.e., networking activities (MARTIN and SUNLEY, 2003). In the US context, some of the literature on high tech development credits the development of successful clusters to the impact of government investment, e.g., in the defence industry, although critics have pointed to enough exceptions to suggest that other factors must be critical to the success of these regions (STORPER, 1997).

ST. JOHN and POUDER (2006) caution that development agencies should be realistic in the type of cluster they pursue, according to their particular geographic and economic strengths. Studies of policy-driven efforts at network building in the UK have indicated that successful networks, i.e. ones that generate lasting inter-firm cooperation, are very difficult to generate without favourable preconditions such as an identifiable issue of common interest or culture of co-operation (ATHERTON, 2003). Therefore intervention in pre-existing informal networks is more successful at generating lasting co-operation than attempting to establish new networks (HUGGINS, 2001). 


\section{ECO-INDUSTRIAL PARKS AS A CLUSTER DEVELOPMENT}

We suggest that by their nature as an agglomeration of businesses with inter-linkages and the expectation of a competitive advantage for participants and economic development benefits for the host community, EIPs can be conceived as a type of cluster policy. In this section we will examine the issue more closely by reviewing the literature on EIPs from the perspective of these three meta-themes.

External economies of scale

Some of the benefits suggested for locating in an EIP are resonant with references in the clusters literature to external economies of scale (e.g., skilled labour supply, shared marketing, and specialist advice) (MARTIN et al., 1998). Some such benefits may relate to environmental issues, such as park-level regulatory compliance, or onsite recycling, but there is nevertheless an awareness of the potential economic benefits (LOWE, 1997; MARTIN et al., 1998). Indeed, in a study of Dutch ecoindustrial parks, PELLENBARG (2002) found that external economies relating to non-environmental activities (e.g., parking facilities or safety systems) were more common than environment-related ones (e.g., utility sharing or heat cascading).

DESROCHERS (2002) points out that an industrial symbiosis network (in which he includes EIPs) is an example of urbanisation agglomeration economies, given that it comprises businesses from a variety of industries, and is not in this respect a novel phenomenon (DESROCHERS, 2002). However, the potential environmental benefits of agglomeration economies are not prominent in the clusters literature (CHERTOW et al., this volume). Industrial ecology features such as shared access to water supply or energy can bring about not only financial savings to the business involved, but also environmental savings (e.g., reductions in total 
water/energy usage) that are of public benefit (CHERTOW et al., this volume).

Furthermore, there are significant distinctions between EIPs and other clusters, especially when the cluster is planned. For example, institutional support can be important in the IE context as with other clusters and university based groups, public agencies or a combination of both are commonly involved (e.g., MARTIN et al., 1998). However, in the IE context, these institutions tend to be more than simply facilitators of collaboration. Rather, they are more likely to be playing a key policy role leading the cluster formation initiative (see under 'policy' below).

Thus there is a significant overlap between the IE and RD literature in the area of external economies of scale, which supports the identification of IE as a cluster perspective in RD terms. Explicit reference to economies accruing from environmental initiatives is distinctive, especially the awareness of those benefits as a public good.

\section{Networking}

One of the distinctive elements of IE amongst eco-efficiency initiatives for business is its emphasis on interfirm co-operation. IE advocates the attempted optimisation of environmental issues on a sectoral or regional scale, rather than at the individual company level. Thus the advantages of clustering accruing from opportunities for face-to-face contact between representatives of different companies and organisations could be of great importance in the context of an EIP. However, we will show that there are critical differences in the expectations placed on networking between IE and RD clusters.

There is appreciation in the IE literature for the social networks highlighted by the New Industrial District (NID) literature. The community of Kalundborg has been compared to a NID in terms of the density of interconnections of social networks 
between representatives of companies involved in the IS network (e.g., GERTLER, 1995; CÔTÉ and COHEN-ROSENTHAL, 1998; STERR and OTT, 2004; D’AMICO et al., 2007). The importance of such links in implementing IE is underscored by D'AMICO et al.'s (2007) study of the policy-initiated formation of an IS network in the Italian Industrial District of Murano, Venice. However, as both RD and IE literature acknowledge, this type of setting is exceptional and certainly cannot be recreated on a policy-relevant time scale.

The networking and trust building that goes into making interfirm relationships possible are not always appreciated in the eco-industrial literature (GIBBS, 2003). There is frequently a more normative concern for matching inputs and outputs (e.g., MARTIN et al., 1998; KINCAID 2003). This concern arises from the premium that the IE literature puts on physical (i.e., material, energy and/or water) exchanges between companies. Whereas in much of the clusters literature the benefits of clustering relate to the potential for personal contact and the generation of untraded interdependencies, in the industrial ecology literature the focus is more firmly on benefits relating to physical transactions (e.g., CÔTÉ and COHEN-ROSENTHAL, 1998; MARTIN et al., 1998). Thus, the focus in IE clusters is not on the benefits of reduced transaction costs in $\mathrm{RD}$ terms, but on the financial rewards of the transactions themselves. In the transaction cost literature the assumption is that a company is achieving economic savings and/or operational flexibility by outsourcing certain of its activities (STORPER, 1997). The cost savings from agglomeration come from the ability to more easily set up arrangements with companies with whom one has a personal connection; it is not any savings in the transactions themselves that are fundamental to the theory (albeit transportation costs may be reduced). By contrast, the economic savings in IE come from the physical transactions themselves, e.g., the 
buying of another company's by-product as opposed to a virgin material. For the company selling the by-product the arrangement is even more beneficial - the cost of disposal of a by-product has become an income through its sale.

However, transactions involving waste materials or energy are often well outside the core interests of a company. This means that many companies are grossly under-informed about the amount and composition of waste they produce, the costs of disposal, and the costs of the raw materials, energy and labour that went into producing their 'waste' (LANDER, 2006). Thus they may have little incentive to explore waste minimisation or more imaginative disposal routes. Moreover, even when the full cost of waste is apparent, it will seldom be a sufficient proportion of a company's expenses to be a significant factor in decisions about where to locate - a significant handicap for planned EIPs (STERR and OTT, 2004). Furthermore, what was once a simple market relationship with a waste disposal company could become a far more complex and collaborative venture with a symbiosis partner. Regulatory issues such as duty of care also make trust a particular concern in the trading of waste (STERR and OTT, 2004). Thus in effect the direct and indirect costs of an industrial symbiosis transaction are likely to be greater than those associated with the alternative.

The volume and frequency of supply as well as its precise composition is likely to be highly significant to a company relying on a by-product as an input to production (SCHLARB, 2001). Since the items in question are by-products, companies cannot readily modify production rate or composition to suit a potential user, in the same manner as they would consider accommodating a new customer for their core products. STERR and OTT (2004) argue that whilst increasing the scale of an industrial symbiosis network from being park-based to that of a region will increase the potential for input-output matches, the difficulty of achieving personal 
contacts is increased. While increasing the scale of search for input-output matches increases the chance of success, there is clearly a distance-decay effect on the economic viability of transporting materials, especially relatively low value ones such as by-products. Furthermore, for energy (heat or steam) transfers, there are technological limitations, such that physical proximity is a necessity (KORHONEN, 2002).

Whilst interfirm co-operation is a central theme of the IE literature, the focus is more on the benefits that would accrue from establishing relationships than on the networking necessary to establish them. Furthermore, we argue that resemblance to the transaction cost perspective is superficial, since the 'costs' of IE 'transactions' are likely to be more expensive than those of more standard options.

Policy

The benefits to business of external economies and interfirm exchanges have been argued to make eco-industrial development useful as an economic development tool (LOWE, 1997; COHEN-ROSENTHAL, 2003). In the US the implementation of industrial ecology in the form of EIPs received federal backing from the Environmental Protection Agency and the President's Council for Sustainable Development. The latter was discontinued in 2000, but the Economic Development Administration (EDA) still offers financial support for eco-industrial developments through its Public Works and Economic Development Investments programme (EDA, 2006). Eco-industrial development as a policy has also been adopted in Europe (notably the Netherlands) (e.g. VAN LEEUWEN et al., 2003; MIRATA, 2004); parts of Asia (e.g., YANG and LAY, 2004) and Australia (ROBERTS, 2004).

There is an on-going debate within the industrial ecology literature as to whether implementation of its principles would be better achieved by planned EIPs or 
evolving IS projects (i.e., self-organising systems) (e.g., CÔTÉ and COHENROSENTHAL, 1998; CHERTOW, 2007) and much of the early optimism for the development of EIPs has given way to pragmatism (CHERTOW, 1999; 2007). DESROCHERS (2002) develops a similar argument to those regional development researchers who argue that clusters cannot be created de novo. However, it is more widely considered that there is a role for the public sector in supporting EIP development (e.g., VAN LEEUWEN et al., 2003; GIBBS and DEUTZ, 2005). There are some similarities between the kinds of limited intervention recommended by regional development analysts regarding cluster policy and those proposed in ecoindustrial developments. COTÉ and COHEN-ROSENTHAL'S (1998) recommendations for developing an EIP, for example, include establishing links between on-site companies and suppliers/customers in the community, establishing a joint training facility, and seeking to attract companies to fill niches. LOWE (1997: 59) urges policy-makers not to 'over-plan'. He sees the public sector role as setting the conditions for businesses to negotiate exchanges. Preparatory activities could include investigating the existing mix of industries in a region to assess potential byproduct flows. COHEN-ROSENTHAL and MCGALLIARD (1998) saw this type of activity as an application of Porter's cluster approach to economic development, i.e., looking for nascent clusters and seeking to develop them. HEERES et al. (2004) compared the experiences of private sector-led EIPs in the Netherlands with those of public sector-led EIPs in the US. They concluded that public sector involvement in EIP development can be a positive hindrance- the privately-led parks they examined had more success at attracting private sector participation.

As with the RD literature, the IE literature identifies economic benefits to communities of hosting a successful cluster. IE-related clusters (i.e., EIPs) have been 
seen as an attractive proposition for sustainable local economic development.

However, the IE literature is divided on the role of policy in cluster establishment between some authors taking an approach akin to the RD literature (favouring cluster evolution). A more widely held view is that there is a role for policy intervention (which varies from facilitation to detailed planning), which distinguishes the IE approach from RD perspectives.

We now turn to an investigation of the issues raised so far through an analysis of empirical data derived from nine US EIPs. Our two aims in this study are to 1) investigate whether IE is simply an environmentally explicitly version of an existing approach to $\mathrm{RD}$, or should it be seen as a distinct perspective; and 2) to derive policy implications for IE and RD of recontextualising IE as a cluster perspective. So far on the basis of our reviews of the treatment of the meta-themes in the IE and RD literature, we have argued that IE-based clusters can be seen as a distinct form of clusters in the RD tradition. We will now investigate that argument further with the data from our case studies. This will also enable us to address our second aim.

\section{RESEARCH METHODS}

The research on which the remainder of this paper is based was conducted in two phases. The initial, extensive, phase of the project identified eco-industrial developments and obtained background information on the characteristics of each initiative through web-based research. We identified over 60 sites worldwide in 2002. However, as sites were predominantly in the U.S.A. (35) and Europe (26), we confined further study to those locations. We attempted to contact a representative of each US and European site in order to validate the Internet data. An email, fax and telephone survey was conducted between January and March 2002. A total of 19 surveys were returned (9 from the USA and 10 from Europe) - see GIBBS et al. 
(2005). We found that many EIPs included on prominent web-lists (e.g., Cornell University Work and Environment Initiative and University of Southern California's Centre for Eco-industrial Development) were either at early stages of development, or already been abandoned; relatively few were operational.

The second, intensive, phase of the research was an in-depth study of selected EIPs involving face-to-face interviews, as well as analysis of secondary materials. Limiting the number of cases examined allowed a far more in-depth approach than could be applied to all cases on a feasible time and expense scale. We concentrated on the US, where there has been a concerted policy drive to establish EIPs and the largest concentration of EIPs in one country. Furthermore, the US sites more explicitly identify themselves with the concept of industrial ecology than the European ones. Projects were selected to represent the range of stages of development (planning to operational) that the EIPs had reached, however none was engaged in by-product exchange at the time of interview. Specific site selection was controlled by their willingness to participate and also 'snowballing' (as in LONGHURST, 2003, p. 124) where the director of one site arranged a visit to one in which he had formerly been involved. In total, we included nine sites, which whilst not a randomly selected sample, covered $50 \%$ of the then active US sites.

At each site up to 8 interviews were carried out with individuals selected from: the park manager, project developer, local authority representative, consultants, participating firms, environmental organisations, community representatives, and the local chamber of commerce. Interviewing multiple representatives of each site enabled a 'triangulation' of factual information and to explore differing perspectives for example, tenants tended to have a less idealistic view of EIPs than developers. The interviews were semi-structured, open-ended and conversational in style (see 
LONGHURST, 2003). We a prepared a list of questions appropriate for each type of person to be interviewed, which covered both the development and operational phases of EIPs. Questions addressed both subjective issues such as the motivations behind setting up the EIP, where the idea for an EIP had come from, and what the interviewees' understood by sustainable development, as well as more factual areas such as how funding was obtained or being sought; and what attempts were being made to, or anticipated for, encouraging networking between site occupants. Interviews were transcribed in full and analysed using the approach that CRANG (2005) terms 'analytic induction' (p. 224). The texts were coded as themes emerged, and re-analysed as new themes emerged and/or our appreciation of existing ones became more nuanced. The use of secondary materials from and relating to the sites provided additional information as well as another form of 'triangulation' to back-up the information from multiple interviewees. We subsequently communicated by email and telephone with park representatives to update park status. Table 1 shows the main features of the case studies used herein based on secondary data. As primary data were collected on the understanding of anonymity, sites have been arbitrarily numbered from 1 to 9 for reference in the main empirical section below. Secondary data are referred to by the name of the park.

Table 1 about here

\section{EIP PROJECTS IN THE U.S.A.}

In this section we review interview, survey and secondary data from each of the sites with respect to the three meta-themes: external economies of scale; networking; and policy. We analyse what the parks envisage(d) and their strategies for implementation, as well as what has so far been achieved in practice.

External economies of scale 
In this section we consider the role that external economies of scale have played in the case study EIPs in order to compare this to their role in the RD concepts of clusters. External economies of scale are an important feature of the advantages that the case study EIPs consider themselves to offer to tenants. For example, the Town of Londonderry website proclaims that the EIP 'allows businesses to save money and work more efficiently through collective environmental management ${ }^{\mathrm{i}}$. Some economies relate to the location of the park in a manner that would apply to any economic development. In this category are economies of scale beyond the park boundary. For example, the location of the Cape Charles EIP was selected for its access to road, rail and port facilities. Economies of scale within EIPs may include shared management and maintenance of building(s) and/or grounds (e.g., Devens, PEEC, Cape Charles, Front Royal, Londonderry). In some cases facilities such as conference and meeting rooms, eating and washroom facilities are shared between tenants (e.g., PEEC). Environmental economies of scale come from communal waste disposal and/or recycling, and utility sharing in the form of renewable energy (e.g. solar energy at Cape Charles, a ground source heat pump at PEEC). These types of features are referred to in promotional material, implying that the EIPs are aware of their economic appeal to potential clients.

One of the primary external economies is access to a shared labour pool. All the EIP case studies have job creation as one of their aims; some have explicitly referred to this as an opportunity for employers. The Cape Charles' web site ${ }^{\text {ii }}$ boasted 'an ample labour pool', which is 'keen to work'. Conversely, Londonderry boasts that New Hampshire has a highly educated citizenry with the highest concentration (per 1000 population) of high-tech workers in the US ${ }^{\mathrm{iii}}$. Three of the EIPs have had a significant involvement with local universities. This engagement has 
taken various forms including park development, research into industrial symbiosis and as potential tenants, while the development team for Ecolibrium is partly based at the University of Texas, Austin. At EIP 4 collaboration took the form of research into potential use of waste heat in aquaculture. At EIP 1 a local university had agreed to use the educational facility that is the centrepiece of the park. Delays in establishing the park have resulted in the university pulling out.

The case study EIPs were all aware of the financial benefits of economies of scale. These include a mix of environmentally focused economies (collective waste removal/recycling) and standard ones, as in the Dutch examples explored by PELLANBURG (2002). The three active sites all offer external economies, including both environmental and more standard ones. In VAN LEEUWEN et al.'s terms all the projects exhibit at least spatial planning and the active ones some form of utility sharing. Thus EIPs fit closely with this aspect of the clusters literature, both in theory and practice, with environmental awareness being an additional distinctive feature.

\section{Networking}

Here we consider the approach that the case study EIPs have taken to networking in order to make a comparison with the RD approach. The goal in all the case study EIPs has been to achieve an agglomeration of interlinked firms. In almost all cases these were envisaged as including energy and/or material exchanges (i.e., transactions). However, some sites are attempting to recruit to a pre-conceived symbiosis network, while others have an open recruitment policy. In the latter case the aim is to promote networking between tenants with a view to assist the evolution of IS on a medium to long time scale. The EIPs attempting to recruit to a symbiosis network are Dallas, Red Hills, and Ecolibrium. EIP 1 is based around a dual recycling and educational theme. The EDA funding that helped develop the site was 
conditional on the recruitment of tenants from a specified range of environmentrelated activities (e.g., recycling, solid waste management, and research into wetlands and waste water treatment). The Red Hills developers have identified a number of potential synergies that would fit with by-products of the operational mine and power station, though other types of businesses would be considered.

The operational and pre-operational US EIPs studied have at least partially separated the processes of attempting to form an initial physical agglomeration of businesses from subsequent attempts to establish a symbiosis network (Cape Charles, Devens, PEEC, Londonderry). Bassett Creek Valley was also envisioned as following this approach. At Front Royal, notwithstanding its identification with the EIP movement, the aim was to establish an office park. In these parks the tenant recruitment phase resembles a standard economic development exercise in attracting inward investment.

The second development phase for these EIPs is building links between tenants. Co-location is only one step towards establishing interfirm linkages:

We realised that we needed to figure out a way to improve communication among the businesses here...[for] the concept of industrial ecology to work that one thing that helps is having businesses in proximity to each other. But another aspect that is really important is that the businesses know what each other is about and that formally or informally linkages can happen. (Environmental Programme Organiser, EIP 8).

A number of strategies have been adopted to encourage networking amongst site occupants. The Londonderry by-laws require occupants to participate in social functions, such as supporting an educational centre to promote the EIP and its practices to the community (TF MORAN INC, undated). At Cape Charles networking, including transactions, was encouraged by a system that rewards socially or environmentally beneficial activities (including working with other companies on how best to meet the environmental goals of the park) by a reduction in rent 
(MCGUIRE et al., undated). Devens has developed a peer recognition scheme (the EcoStar Program) for environmental and/or social accomplishments including byproduct exchange ${ }^{\mathrm{iv}}$.

EIP organisers appreciate that they cannot force linkages, certainly not in terms of materials exchanges, for which there needs to be a match of supply and demand in terms of quantity and quality of material. However, networking events can help to set the pre-conditions for exchanges:

It could build some of these relationships. It is already starting to do that with the steering committee, build some relationships among the businesses here so that they're more likely to do the exchanges if the exchanges make economic sense for them. (Environmental Programme Organiser, EIP 8).

However, there is little evidence of industrial symbiosis at our case studies - none of our case studies meet CHERTOW's (2007) definition of an industrial symbiosis network, although only Front Royal has dropped its networking aspirations altogether. Devens is a modest example of symbiosis, but is actively encouraging more. The power plant at Londonderry uses waste water for cooling purposes and the ash from the power station at Red Hills is recycled into cinder blocks off-site. PEEC is involved in neighbourhood scale efforts; although the current mix of tenants makes this unrealistic within the building itself. At Dallas recruitment has been too slow to make industrial symbiosis feasible yet. The sites that have been most successful at recruiting tenants have not been restrictive in their recruitment policy. However, the consequently diverse and unplanned mixture of tenants has contributed to the difficulties in establishing symbiosis beyond a token level. For example, tenants at EIP 8 claimed particular circumstances militate against participating in by-product exchanges. One firm, carrying out pharmaceutical R\&D is banned by the Food and Drug Agency from using recycled goods. That company's by-products are classified as hazardous waste and are sent for incineration. Another company manufactures 
parts for aircraft and claim quality as their priority in sourcing materials to ensure product performance.

The tenants who were interviewed were not well informed on the principles of industrial ecology. In every case they had moved only because the company was looking to relocate or expand and the location suited: 'Initially [an EIP] wasn't what we were looking for when we moved up here... we were looking for a new facility, a place to build, and something that was centrally located to access our customers' (Company Representative, EIP 8). However, aside from the locations, aspects of the parks were attractive, such as links between Devens and the state Environmental Protection Agency (EPA), which smoothed the permitting process. At Red Hills a new tenant will use coal from the mine to research and demonstrate a technology for converting coal into a liquid fuel ${ }^{v}$. The locational decision appears to have included a very traditional concern to minimise the transportation costs of the major raw material, aided by grants from the Mississippi Development Agency.

Devens' pro-active approach to bringing firms together has resulted in collaborations, albeit so far only minimal symbiosis. Interviewees from two firms participating in the steering group setting up Devens' incentive scheme have established a functional relationship with each other and a third firm. Collaborations between these firms include purchase of safety equipment, investigating joint recycling of waste, and exchange of information on safety procedures. At EIP 3 networking initiatives have been less pro-active and less successful. One tenant had been attracted by the spirit of the enterprise and the environmental standards of the building. He and another tenant at the same park had both expected more networking opportunities than have materialised. The park has an e-newsletter as well as a variety 
of shared facilities, but this appears to have had a limited effect on communication, let alone collaboration.

To a variable extent, the active parks are promoting networking between existing tenants not unlike more conventional clustering activities (BENNEWORTH et al., 2003)). Spatial proximity and commitment to sustainability required by some of these sites means they are starting the cluster formation process with potentially favourable pre-conditions. A newly formed park is an agglomeration of businesses somewhere between the level of 'potential' and 'emerging' cluster (ATHERTON, 2003): that is, common interests and need or opportunity for co-operation has been identified, but is at a preliminary level regarding trust building. Potentially, an EIP already has 'the development of mutual awareness and a local common enterprise' (RACO, 1999: 956) regarded as necessary for the formalisation of clusters. This is supported by the willingness of tenants to participate in networking activities, notwithstanding that they had located in an EIP largely for non-environment related reasons. The choice of location may also indicate a preparedness to engage in networking activities outside core company activities (c.f., MORGAN et al., 2000). However, the tenants interviewed were environmental managers of multinational companies. Therefore, environmental issues are core to their own interests, even if not to the company as a whole.

Networking related ideas and activities have been fundamental to the sites studied. However, recruitment is a necessary precursor to networking and the regional setting appears to be a stronger determinant of recruitment success than variations in the approach of the parks. The difficulty of exploiting interfirm relationships to achieve physical flows between firms is evident from the lack of a significant IS network at any of these EIPs. The experience of the case study EIPs 
also cautions against seeing EIP status as a factor likely to promote efforts at creating a cluster de novo. Several parks have had to downgrade or abandon their environmental aims, suggesting an initial under-appreciation of the challenges they faced.

\section{Policy}

In this section we consider the role of policy in the development of the case study EIPs, in order to compare this to the role of policy in RD clusters. All of the EIPs studied are planned initiatives, chiefly aimed at re-developing specific brownfield sites, but with no pre-existing tenants. In all cases (based on survey, interview and secondary data) there is an expectation that the development would generate benefits for the communities in which they are situated. Indeed, most are public sector initiatives led by economic development agencies (see Table 1). Cape Charles, Devens, Londonderry, and Bassett Creek Valley were initiated as part of larger sustainability agendas, whereas others (e.g., Front Royal, Dallas, Red Hills) are more isolated sustainability initiatives for agencies whose primary function is economic development. Londonderry was initiated by the town's Planning and Economic Development Department, but the town's inability to afford to develop the site itself has meant that it was sold to a private developer and is the only site to be developed by private sector funding (LOWITT, 2003). Nevertheless, the site was sold on the condition that vision of the planners was implemented via a strict set of covenants (LOWITT, 2003). The PEEC is exceptional in that it is a community-led initiative. However, it is aimed precisely at attracting economic benefits in an environmentally-friendly context to a deprived neighbourhood ${ }^{\mathrm{vi}}$.

As stated, all the EIPs studied were planned, and all but two were public sector-led. The three that have been the most successful at tenant recruitment so far 
are Devens and both of the exceptions to public sector status: PEEC is community-led and Londonderry was privately developed following a public sector initiative. Red Hills and Dallas remain at early stages of development. The Dallas Eco Business Park is an on-going development project for the City of Dallas. Front Royal is actively recruiting companies, but the environmental theme has been played down. The Avtex Fibres website currently refers to 'eco-friendly office space'vii, a step removed from the previous planned 'eco-office park', which was already a step back from the earlier interest in an 'eco-industrial park'. Eco-industrial principles could yet be an element of the redevelopment of Bassett Creek Valley, but the City-led redevelopment is still at the planning stages. The Austin EIP does not appear to have progressed beyond conceptual stages. The Cape Charles EIP has closed as a result of difficulties in recruiting tenants.

Whilst the IE literature is divided on the possibilities for implementation of its principles via the planned formation of EIPs, this is precisely what has been attempted by each of the case studies. Furthermore, although the net result of the difficulties in establishing symbiosis is that EIPs in practice resemble standard clusters far more than EIPs in theory, the distinction is still important. Labelling themselves as EIPs does make EIPs distinct. This can either help or hinder recruitment, but means that they are judged by additional criteria for success compared to standard local development projects. Furthermore, whilst EIP status may open up alternative funding sources, these may limit recruitment options (as at EIP 1). In other words, in being more ambitious than more conventional development projects, EIPs may compromise their ability to succeed on any level.

CONCLUSIONS 
The main aim of this paper has been to examine whether EIPs can be conceptualised as an environmentally-based variant of a cluster strategy and to consider the policy implications of such a re-conceptualisation. We have argued that whilst EIPs have important features in common with more mainstream conceptualisations of clusters, there are significant differences in economic as well as environmental terms.

Common features include the use of EIPs as economic development initiatives as well as an appreciation of the economic significance of both external economies of scale and networking. A major distinguishing feature of EIPs is that development agencies are typically trying to build clusters de novo, rather than enhance existing ones. However, more significant differences between EIPs and other clusters are an awareness of the environmental benefits of agglomeration (CHERTOW et al., this volume), awareness of economic benefits in environmental practices, the nature of the envisaged transactions between cluster members and the sources of cost savings if those transactions were realised. The physical exchanges characteristic of an industrial symbiosis cluster are not a trivial variation on the clustering theme. Symbiosis transactions by their very nature involve by-product material and energy exchanges. These will be of lower value and less interest to a firm than its products, but may nonetheless involve issues of confidentiality. It is the need for, and the nature of, the transactions that make EIPs a highly ambitious cluster strategy. Neither localisation economies from companies in a given sector (all with similar input needs and by-products to each other), nor urbanisation economies from companies in a broad collection of industries will necessarily offer potential material or energy exchanges. Thus whilst EIPs have commonalities with other cluster perspectives in terms of their engagement with the three meta-themes, they do not fit comfortably into any of the recognised cluster perspectives. 
Policy implications of EIPs as a cluster perspective

The second aim of the study was to derive the policy implications of conceptualising EIPs as a distinct cluster perspective. This is especially pertinent in the light of the significant gap between EIP aspiration and achievement that we have highlighted. Implications for regional development

Some of these initiatives are being led by economic development agencies (Table 1); others can learn from these attempts to infuse IE principles into RD initiatives. The shortfall in IE results compared to expectations sends a clear cautionary signal that attempting to implement the principles of IE will not provide a simple, economically advantageous means to address environmental issues in a local or regional development strategy. The practical difficulties of IE implementation are best understood if it is acknowledged that EIPs are 'clusters' and will share the common difficulties and uncertainties of other cluster approaches in terms of transferring the successful features from one location to another. Some of the case study EIPs are in locations where attracting other forms of economic development generally has proved difficult. Opting for an IE approach has not therefore been a way to transcend economic and geographic realities. It is also necessary to understand the distinctiveness of EIPs in cluster terms in order to appreciate the economic realities of the beguiling simplicity of the ecological metaphor. The distinctive features of EIPs as clusters include the need for physical exchanges, which can involve complex negotiations/technical arrangements pertaining to items which for potential symbiosis partners are low priority items. For many firms these may simply be items they wish to dispose of without incurring excessive costs or uncertain liabilities. Such factors significantly add to the challenges involved.

Implications for IE 
Importantly, the clusters literature indicates the uncertainty of defining what is generating the success of successful regions and, therefore, what policy makers should be attempting to emulate (MARTIN and SUNLEY, 2003). Most of the cluster concepts, such as New Industrial Districts, or transaction costs approaches apply to specific, limited circumstances (STORPER, 1997). The recognition of the importance of institutions in economic development could suggest a possible pathway for policy, but is no guarantor of success: 'while in some circumstances different places can learn from each other, in general there are few easy opportunities to borrow institutions. Instead there is the complex task of institution building appropriate to the social, economic, legal and cultural norms of different localities' (NEWLANDS, 2003: p. $530)$.

Significantly, for EIPs, economic success and ability to construct a symbiosis network do not necessarily go together. Whether the environmental theme of the case study developments sets a higher hurdle for tenant recruitment compared to other cluster initiatives, or acted as a useful tool for market differentiation, their economic success ultimately reflects factors beyond the control of developers. However, the experiences of the active EIPs, and Devens in particular, indicates what can be achieved when developers focus first on the characteristics of EIPs that they can control and second on providing the pre-conditions for more elusive ones to evolve. The environmental achievements of both EIPs that are financially viable and those that are less so are dominated by 'economy of scale' features such as environment award-winning premises and environmentally sympathetic landscaping. These may be desirable ends in their own right, but represent at best a partial success as an EIP. However, these types of initiatives can be precursors to closer co-operation. The clusters literature suggests that generating successful networks, i.e. ones that generate 
lasting inter-firm co-operation, requires favourable preconditions such as an identifiable issue of common interest or culture of co-operation (GERTLER, 1995, HUGGINS, 2001). Location within an EIP may provide the proximity to overcome the largest problem for small companies, i.e., time (HUGGINS, 2001). The EIP setting helps to provide organisational as well as geographical proximity (TORRE and GILLY, 2000; BOSCHMA 2005). However, the case study interviews indicate that this organisational proximity is not yet well developed. There is a lack of social depth to the contacts at present, compared to those characteristic of new industrial districts (AMIN, 2000). Devens has been more successful than the other active sites at building on successful spatial planning or utility sharing (c.f., VAN LEEUWEN et al., 2003) to achieve inter-firm networking, albeit that symbiosis has yet to develop. The difference between Devens and PEEC and Londonderry EIPs in this regard is the EcoStar programme, which provides both incentives for collaboration and opportunities for contact. Thus for any policy-driven network a high level and protracted period of intervention is required to crystallise the potential for apparently spontaneous inter-firm co-operation to come about. For those EIPs that have struggled to achieve financial sustainability, an appreciation of the clusters literature might have helped to guide their expectations and approach to tenant recruitment. EIPs 3 and 7 both expressed disappointment that whilst they had initially identified tens of potential tenants, very few would even consider relocating. The would-be tenants had good reasons to be where they were already. Having a clear theme to EIP developments was not in and of itself a magnet to tenants, even those whose business fitted squarely into the theme. Local authorities should not abandon their economic development objectives simply because there are clear challenges to achieving them. They should also not abandon their environmental principles, indeed a number of the 
case study sites have selected eco-industrial development in reaction to environmental problems generated by former activities. However, they should be realistic as to the strengths and weaknesses of their locality, and should be cautious in their decision to aim for this specialised and distinct type of clustering represented by EIPs. This realism can only be aided by the awareness that EIPs are one of a number of forms of cluster and an appreciation of the mainstream perspectives on clustering.

Acknowledgements - This paper is derived from a study of eco-industrial parks funded by the UK Economic and Social Research Council (Grant number R000239428). We also acknowledge the support of the Hull Environment Research Institute. We are grateful to all the interviewees for their co-operation. We thank Angela Hull, Andy Jonas and the anonymous reviewers for their helpful comments. All errors and omissions remain the responsibility of the authors.

\section{REFERENCES}

ALLENBY, B.R. (1999) Industrial Ecology: Policy Framework and Evaluation. Prentice Hall, Eaglewood Cliffs.

AYRES, R.U. (1989) Industrial metabolism. In Ausubel J and Sladovich HE (Eds) Technology and Environment National Academy Press Washington DC. ANDREWS C.J. (1999) Putting industrial ecology into place; Evolving roles for planners, Journal of the American Planning Association 65, 364-375.

AMIN A. (1999) An institutional perspective on regional economic development, International Journal of Urban and Regional Research 23, 365-378.

AMIN A. (2000) Industrial districts, in E. SHEPHERD and T.J. BARNES (Eds) $A$ Companion to Economic Geography, pp. 149-168, Blackwell, Oxford. 
ATHERTON A. (2003) 'Examining clusters formation from the 'bottom-up': an analysis of four cases in the north of England', Environment and Planning C: Government and Policy 21, 21-35.

BAAS F.A. and BOONS L.W. (2004) An industrial ecology project in practice: exploring the boundaries of decision-making levels in regional industrial systems, Journal of Cleaner Production 12, 1073-1085.

BATHELT H. (2005) Cluster relations in the media industry: Exploring the 'distanced neighbour' paradox in Leipzig, Regional Studies 91, 105-127.

BENNEWORTH P., DANSON M., RAINES P. and WHITTAM G. (2003) Confusing clusters? Making sense of the cluster approach in theory and practice, European Planning Studies 11, 511-520.

BENNEWORTH P. and HENRY N. (2004) Where is the value added in the cluster approach: Hermeneutic theorising, economic geography and clusters as a multiperspectival approach, Urban Studies 41, 1011-1023.

BOSCHMA, R.A. (2005) Proximity and Innovation: A Critical Assessment, Regional Studies 39 (1), 61-74.

CAMAGNI R. (1991) Innovation networks: Spatial perspectives. Belhaven, London. CHERTOW M.R. (1999) The Eco-industrial park model reconsidered. Journal of Industrial Ecology 2 (3) 8-10.

CHERTOW M.R. (2000) Industrial Symbiosis: Literature and Taxonomy, Annual Review of Energy and Environment 25, 313-337.

CHERTOW M.R. (2007) “Uncovering” industrial symbiosis, Journal of Industrial Ecology 11, 11-30. 
CHERTOW M.R., ASHTON W.S. and ESPINOSA J.C. (accepted) Industrial Symbiosis in Puerto Rico: Environmentally Related Agglomeration Economies, submitted to Regional Studies.

COHEN-ROSENTHAL E. (2003) What is eco-industrial development? In COHENROSENTHAL E. and MUSNIKOW J. (Eds) Eco-industrial strategies: unleashing the synergy between economic development and the environment, pp. 14-29. Greenleaf Publishing, Sheffield.

COHEN-ROSENTHAL E. and MCGALLIARD, T.N. (1998) 'Eco-industrial development: the case of the United States', Institute for Prospective Technological Studies Report, 27 unpaginated. $\underline{\text { www.jrc.es/pages/f-report.en.html }}$

CÔTÉ R. P. and COHEN-ROSENTHAL E. (1998) 'Designing eco-industrial parks: a synthesis of some experiences', Journal of Cleaner Production 6, 181-188.

CRANG M. (2005) Analysing qualitative methods, in Flowerdew R. and Martin D. (Eds) Methods in Human Geography, pp. 218-232. Pearson, Harlow.

CUMBERS A. and MACKINNON (2004) Introduction: Clusters in urban and regional development, Urban Studies 41, 959-969.

D’AMICO F. BULEANDRA MM VELARDI M AND TANASE I (2007) Industrial ecology as 'best available technique': A case study of the Italian industrial district of Murano, Venice. Progress in Industrial Ecology 4 268-287.

DESROCHERS P. (2002) Cities and Industrial symbiosis: Some historical perspectives and policy implications, Journal of Industrial Ecology 5, 29-44.

ECONOMIC DEVELOPMENT ADMINISTRATION (2006) FY 2006 Economic

Development Assistance Programmes.

http://www.eda.gov/InvestmentsGrants/FFON.xml; accessed 17/1/07. 
FROSCH R.A. and GALLOPOULOS N.E. (1989) Strategies for manufacturing, Scientific American 261, 94-102.

GERTLER N. (1995) Industrial Ecosystems: Developing sustainable industrial structures. MSc thesis, MIT.

http://www.smartcommunities.ncat.org/business/gertler2.shtml accessed 5.3.07.

GIBBS D. (2003) Trust and networking in inter-firm relations: the case of ecoindustrial development, Local Economy, 18, 222-236.

GIBBS D. (2006) Prospects for an environmental economic geography: linking ecological modernization and regulationist approaches, Economic Geography, 82, 193-215.

GIBBS D. and DEUTZ P. (2005) Implementing Industrial Ecology? Planning for ecoindustrial parks in the USA. Geoforum 36, 452-464.

GIBBS D., DEUTZ P. and PROCTOR A. (2005) Industrial ecology and ecoindustrial development: A new paradigm for local and regional development? Regional Studies 39, 171-183.

HAUGHTON G. and COUNSELL D. (2004) Regions, Spatial Strategies and Sustainable Development. Routledge, London

HEERES, RR, VERMEULEN WJV, and DE WALLE, FB (2004) Eco-industrial park initiatives in the USA and the Netherlands: first lessons, Journal of Cleaner Production 12 985-995.

HENDRY C. and BROWN J. (2006) Dynamics of clustering and performance in the UK opto-electronics industry. Regional Studies 40 (7) 707-725.

HOWELLS J.R.L. (2002) Tacit knowledge, innovation and economic geography, Urban Studies 39, 871-884. 
HUGGINS R. (2001) Inter-firm network policies and firm performance: evaluating the impact of initiatives in the United Kingdom, Research Policy 30, 443-458.

JONAS A.E.G. and PINCELT S. (2006) Rescaling regions in the state: The New Regionalism in California. Political Geography, 25, 482-505.

KINCAID J. (2003) Metropolitan Industrial ecosystem development, in BOURG D. and ERKMAN S. (Eds) Perspectives on industrial ecology, pp. 95-100. Greenleaf Publishing, Sheffield.

KORHONEN J. (2001) Four ecosystem principles for an industrial ecosystem Journal of Cleaner Production 9, 253-259.

KORHONEN J. (2002) Two paths to industrial ecology: applying the product-based and geographical approaches, Journal of Environmental Planning and Management 45, 39-57.

LANDER, T. (2006) Director, Humber Resource Efficiency Centre Ltd. Personal communication.

LONGHURST R. (2003) Semi-structured interviews and focus groups, in CLIFFORD N.J. and VALENTINE G. (Eds) Key Methods in Geography, pp. 117132. Sage, London.

LOVERING J. (1999) Theory led by policy: The inadequacies of the 'New Regionalism' (Illustrated from the case of Wales), International Journal of Urban and Regional Research 23, 379-395.

LOWE E.A. (1997) Creating by-product resource exchanges: strategies for ecoindustrial parks, Journal of Cleaner Production 5, 57-65.

LOWITT P. (2003) Sustainable Londonderry, in COHEN-ROSENTHAL E. and MUSNIKOW J. (Eds) Eco-industrial strategies: unleashing the synergy between 
economic development and the environment, pp. 288-299. Greenleaf Publishing, Sheffield.

MARTIN R. and SUNLEY P. (2003) Deconstructing clusters: chaotic concept or policy panacea? Journal of Economic Geography 3, 5-35.

\section{MARTIN S.A., CUSHMAN R.A., WETZ K.A., SHARMA A. and LINDROOTH R.C. (1998) Applying industrial ecology to industrial parks: an economic and environmental analysis, Economic Development Quarterly 12, 218-237.}

MACKINNON D., CUMBERS A. and CHAPMAN K. (2002) Learning, innovation and regional development: a critical appraisal of recent debates, Progress in Human Geography 26, 293-311.

MARSHALL A. (1890) Principles of Economics, London, Macmillan.

MCGUIRE, WOODS, BATTLE AND BOOTHE, L.L.P. (undated) Application for occupancy within the Port of Cape Charles Sustainable Technologies Industrial Park.

MIRATA M. (2004) Experiences from early stages of a national industrial symbiosis programme in the UK: determinants and co-ordination challenges, Journal of Cleaner Production 12 967-984.

MORGAN B., BROOKSBANK D. and CONNOLLY M. (2000) The role of networking in the new political economy of regional development', European Planning Studies 8, 319-336.

MORGAN K. (1997) The Learning region: Institutions, innovation and regional renewal, Regional Studies 31, 491-503.

MORGAN, K. (2004) The exaggerated death of geography: learning, proximity and territorial innovation systems, Journal of Economic Geography 4, 3-21. 
NEWLANDS, D. (2003) Competition and co-operation in industrial clusters: The implications for public policy, European Planning Studies 11, 521-532.

PELLENBARG P.H. (2002) Sustainable business sites in the Netherlands: a survey of policies and experiences, Journal of Environmental Planning and Management 45, 59-84.

PERRIN J.C. (1993) Pour une révision de la science régionale: l'approche en termes de milieu. Centre d'Economie Régionale, University of Aix-Marseille, Aix-enProvence, 148(3).

PIORE M. and SABEL C. (1984) The Second Industrial Divide. Basic Books, New York.

PORTER M. (1998) Clusters and the new economics of competition. Harvard Business Review 76, 77-91.

PRESIDENT'S COUNCIL FOR SUSTAINABLE DEVELOPMENT (1997) EcoIndustrial Park Workshop Proceedings, October 17-18, 1996, Cape Charles, Virginia. Accessed 10.05.02 http://clinton2.nara.gov/PCSD/Publications/Eco_Workshop.html

RACO M. (1999) Competition, collaboration and the new industrial districts:

Examining the institutional turn in local economic development, Urban Studies 36, 951-968.

ROBERTS B.H. (2004) The application of industrial ecology principles and planning guidelines for the development of eco-industrial parks: an Australian case study, Journal of Cleaner Production 12, 997-1010.

SAXENIAN, A. (1995) The genesis of Silicon Valley, in HALL P. and MARKUSEN A. (Eds) Silicon Landscapes. Allen \& Unwin, Boston. 
SCHLARB, M. (2001) Eco-industrial Development: A Strategy for Building Sustainable Communities, Cornell University/Washington DC: United States Economic Development Administration.

SCOTT A. (1988) Metropolis: From the division of labour to urban form. University of California Press, Berkeley.

SCOTT J.W. (2007) Smart Growth as urban reform: A pragmatic 'recoding' of the new regionalism. Urban Studies 44 15-35.

STERR T. and OTT T. (2004) The industrial region as a promising unit for ecoindustrial development - reflections, practical experience and establishment of innovative instruments to support industrial ecology, Journal of Cleaner Production 12, 947-965.

ST. JOHN C.H. and POUDER R.W. (2006) Technology clusters versus industry clusters: Resources, Networks, and regional advantages, Growth and Change 37, 141-171.

STORPER, M. (1997) The regional world: Territorial development in a global economy. The Guildford Press, New York.

SYDOW, J and STABER, U (2002) The institutional embeddedness of project networks: The case of content production in German Television, Regional Studies, 36(3), 215-227.

TF MORAN INC. (undated) Londonderry EcoPark: Industry and the environment - a module for future sustainable development.

TORRE A. and GILLY J-P. (2000) On the analytical dimension of proximity dynamics, Regional Studies 34, 169-180. 
1

2

3

4

5

6

7

8

9

10

11

12

13

14

15

16

17

18

19

20

21

22

23

24

25

26

27

28

29

30

31

32

33

34

35

36

37

38

39

40

41

42

43

44

45

46

47

48

49

50

51

52

53

54

55

56

57

58

59

60

VAN LEEUWEN M.G., VERMEULEN W.J.V. and GLASBERG P. (2003) Planning eco-industrial parks: an analysis of Dutch methods, Business Strategy and the Environment 12, 147-162.

WELLS P. (2006) Re-writing the ecological metaphor: Part I, Progress in Industrial Ecology 3, 114-128.

YANG P P-J. and LAY O.B. (2004) Applying ecosystem concepts to the planning of industrial areas: a case study of Singapore's Jurong Island, Journal of Cleaner Production 12, 1011-1023. 
Table1. Main Features of Eco-industrial Developments in Interview Survey (developed from Gibbs and Deutz, 2005)

\begin{tabular}{|c|c|c|c|c|c|}
\hline Park & Location & $\begin{array}{l}\text { Developer and } \\
\text { Funding }\end{array}$ & Objectives & 'Greenness' & Status \\
\hline $\begin{array}{l}\text { Devens Planned Community, } \\
\text { MA }\end{array}$ & Former army base, rural area & $\begin{array}{l}\text { Public - } \\
\text { including } \\
\text { Federal }\end{array}$ & $\begin{array}{l}\text { Balancing economic } \\
\text { development, } \\
\text { environmental } \\
\text { performance and social } \\
\text { values }\end{array}$ & $\begin{array}{l}\text { Developing Eco Star Program } \\
\text { to promote environmental } \\
\text { achievements including IS; } \\
\text { green building incentives }\end{array}$ & $\begin{array}{l}\text { Opened 1996; } 75 \text { tenants; } 4,000 \\
\text { jobs; EcoStar programme in } \\
\text { place }\end{array}$ \\
\hline $\begin{array}{l}\text { Phillips Eco Enterprise } \\
\text { Center, MN }\end{array}$ & $\begin{array}{l}\text { Urban area, deprived } \\
\text { neighbourhood }\end{array}$ & $\begin{array}{l}\text { Community } \\
\text { group; public } \\
\text { (state, county } \\
\text { and city) \& } \\
\text { private }\end{array}$ & $\begin{array}{l}\text { Living wage jobs, clean } \\
\text { industries }\end{array}$ & $\begin{array}{l}\text { Architecture, some 'green' } \\
\text { tenants; links with the } \\
\text { community and planning CHP } \\
\text { plant }\end{array}$ & $\begin{array}{l}\text { Opened 1999; no IS on site, but } \\
\text { involved in neighbourhood } \\
\text { projects }\end{array}$ \\
\hline $\begin{array}{l}\text { Port of Cape Charles } \\
\text { Sustainable Technology Park, } \\
\text { VA }\end{array}$ & $\begin{array}{l}\text { Rural location in transition } \\
\text { from agriculture and food } \\
\text { processing to service economy }\end{array}$ & $\begin{array}{l}\text { County } \\
\text { economic } \\
\text { development } \\
\text { agency; public } \\
\text { (county, federal } \\
\text { and state) } \\
\end{array}$ & $\begin{array}{l}\text { Creation of living wage } \\
\text { jobs in context of } \\
\text { sustainable } \\
\text { development }\end{array}$ & $\begin{array}{l}\text { Architecture, covenants, points } \\
\text { system }\end{array}$ & $\begin{array}{l}\text { Opened } 2000 \text { but limited } \\
\text { recruitment; offered for sale for } \\
\text { private development in } 2004\end{array}$ \\
\hline $\begin{array}{l}\text { Londonderry Eco-industrial } \\
\text { Park, NH }\end{array}$ & $\begin{array}{l}\text { Small community with } 2 \\
\text { superfund sites, adjacent to } \\
\text { airport and freeway to Boston }\end{array}$ & $\begin{array}{l}\text { Commercial } \\
\text { developer; } \\
\text { private }\end{array}$ & $\begin{array}{l}\text { Strengthen local } \\
\text { economy, reduce } \\
\text { environmental impacts }\end{array}$ & $\begin{array}{l}\text { Covenants, architecture, gas } \\
\text { fired power plant as anchor } \\
\text { tenant, uses treated wastewater } \\
\text { from near-by town }\end{array}$ & $\begin{array}{l}\text { Opened 2003; limited } \\
\text { recruitment, covenants still in } \\
\text { place now overseen by local } \\
\text { authority }\end{array}$ \\
\hline Red Hills Ecoplex, MS & $\begin{array}{l}\text { Rural location, next to lignite } \\
\text { mine and power plant, high } \\
\text { job losses }\end{array}$ & $\begin{array}{l}\text { County } \\
\text { economic } \\
\text { development } \\
\text { foundation; } \\
\text { public (State) }\end{array}$ & $\begin{array}{l}\text { Job creation in } \\
\text { sustainable context }\end{array}$ & $\begin{array}{l}\text { Recruiting for loop closing, } \\
\text { power plant as anchor tenant }\end{array}$ & $\begin{array}{l}\text { Anchor businesses in place } \\
\text { 2003, tenant recruitment on- } \\
\text { going, now less focused on } \\
\text { prescribed symbioses. }\end{array}$ \\
\hline $\begin{array}{l}\text { Dallas Eco-industrial Park, } \\
\text { TX }\end{array}$ & $\begin{array}{l}\text { Adjacent to landfill in } \\
\text { underdeveloped } \\
\text { neighbourhood, South Dallas }\end{array}$ & $\begin{array}{l}\text { City economic } \\
\text { development and } \\
\text { brownfield } \\
\text { development } \\
\text { departments; } \\
\text { public (Federal } \\
\text { and city) }\end{array}$ & $\begin{array}{l}\text { Job creation, } \\
\text { neighbourhood } \\
\text { redevelopment }\end{array}$ & $\begin{array}{l}\text { Environmental education, } \\
\text { recycling }\end{array}$ & $\begin{array}{l}\text { Educational building open } \\
\text { 2003; recruitment slow }\end{array}$ \\
\hline
\end{tabular}




\begin{tabular}{|c|c|c|c|c|c|}
\hline $\begin{array}{l}\text { Ecolibrium, Computer and } \\
\text { Electronic Disposition, } \\
\text { Austin, TX }\end{array}$ & $\begin{array}{l}\text { Outskirts of Austin on major } \\
\text { landfill site }\end{array}$ & $\begin{array}{l}\text { Consortium - } \\
\text { university based, } \\
\text { private sector } \\
\text { and federal } \\
\text { economic } \\
\text { development } \\
\text { agency; public } \\
\text { (Federal) }\end{array}$ & $\begin{array}{l}\text { Reduced waste to } \\
\text { landfill, job creation }\end{array}$ & $\begin{array}{l}\text { Recycling computers \& } \\
\text { electronic equipment }\end{array}$ & Planned; grant from EDA \\
\hline $\begin{array}{l}\text { Front Royal, Eco Office Park, } \\
\text { VA }\end{array}$ & $\begin{array}{l}\text { Washington DC commuter } \\
\text { belt, superfund site }\end{array}$ & $\begin{array}{l}\text { Town/county } \\
\text { economic } \\
\text { development } \\
\text { authority; public } \\
\text { (Federal), private } \\
\text { (company liable } \\
\text { for clean-up) }\end{array}$ & $\begin{array}{l}\text { Jobs for residents, } \\
\text { reduce commuting } \\
\text { outside town }\end{array}$ & Architecture, networking & $\begin{array}{l}\text { Major progress in clean up, } \\
\text { historic building restored as } \\
\text { main office, but 'eco' } \\
\text { credentials now dropped }\end{array}$ \\
\hline Bassett Creek, MN & $\begin{array}{l}\text { Industrial/commercial site } \\
\text { north of downtown } \\
\text { Minneapolis }\end{array}$ & $\begin{array}{l}\text { Consultants; } \\
\text { public (city) }\end{array}$ & $\begin{array}{l}\text { Creating labour } \\
\text { intensive businesses }\end{array}$ & $\begin{array}{l}\text { Networking - energy, materials, } \\
\text { personnel }\end{array}$ & $\begin{array}{l}\text { The neighbourhood } \\
\text { redevelopment initiative still in } \\
\text { planning stages }\end{array}$ \\
\hline
\end{tabular}


Notes

\footnotetext{
${ }^{\mathrm{i}}$ http://www.londonderrynh.org/planning/whylocateinlondonderry.pdf Accessed 15/01/07.

${ }^{i i}$ http://www.sustinablepark.com/labor/html; Accessed 11.03.04.

iii http://www.londonderrynh.org/planning/whylocateinlondonderry.pdf Accessed 15/01/07.

${ }^{\text {iv }}$ http://www.ecostardevens.com/index_files/Page435.htm Accessed 8/03/08.

${ }^{\mathrm{v}}$ http://www.silverado.com Accessed 17/01/07.

${ }^{\text {vi }}$ http://www.greeninstitute.org/ Accessed 15/01/07.

vii http://www.avtexfibers.com/HomeMain.htm Accessed 16/01/07.
} 